\title{
Personalisation of power, neoliberalism and the production of corruption
}

\author{
Amal Hayati Ahmad Khair ${ }^{\mathrm{a}}$, Roszaini Haniffa ${ }^{\mathrm{b},}$, Mohammad Hudaib ${ }^{\mathrm{c}}$, Mohamad Nazri
} Abd. Karim ${ }^{\mathrm{a}}$

a Department of Accounting and Finance, Hull University Business School, UK b School of Management and Languages, Heriot-Watt University, Scotland, UK c Adam Smith Business School, University of Glasgow, Scotland, UK

* Corresponding author. Tel.: +44 01314518348.

E-mail address: r.haniffa@hw.ac.uk (R. Haniffa).

"Those who are in authority are of two groups: the scholars and the rulers. If they are upright, the people will be upright; if they are corrupt, the people will be corrupt."

(Ibn Taymiyyah)

\begin{abstract}
This paper utilises a political lens in considering the cause for the production of corruption and the role of political leadership. Specifically, the notion of personalisation of power as advocated by Slater (2003) is adopted to portray how the adoption of neoliberalism ideology by an aspiring autocratic leader results in the weakening of the infrastructural power through three strategies: packing, rigging and circumventing. We use Perwaja Steel as a case study to demonstrate the modus operandi of corruption in a state-owned enterprise in Malaysia.
\end{abstract}

Key words: corruption, neoliberalism, personalisation of power, Perwaja Steel, crony capitalism, Malaysia 


\section{Personalisation of power, neoliberalism and the production of corruption}

\section{Introduction}

Malaysia is often quoted as a good example of a successful moderate Islamic country (Borneopost, 28 June 2012). It is ranked as the " $37^{\text {th }}$ best country in the world and among the top three Asian countries in the global standing” for doing business (The Staronline, 21 August 2010), and is also a world leader for Islamic finance. Despite its impressive achievements, there are increasing underlying concerns over the last two decades on the growth and persistence of corruption in the country, which is not only destroying its international reputation as a safe and equitable environment for investment but also immensely harming the quality of life of its people (Ibrahim, 2013). According to the Malaysian Anti-Corruption Commission, prosecution of corruption cases in the form of bribery, malpractices, abuse of power, criminal breach of trust, and misappropriation of funds has increased to 520 cases during 2011 as compared to 432 cases in 2010 (MACC, 2012). In fact, Malaysia is ranked fifth (after China, Russia, Mexico, and India) among the top 10 countries for illicit capital flight, accounting for almost 40.3 percent of cumulative illicit financial flows from developing countries between 2003 to 2012 and ranked third (after China and India) among Asian countries in exporting illicit capital to rich countries (Global Financial Integrity, 2014). In spite of the major reforms in curbing corruption being launched by the past and current governments, it has continued to slide down in the Corruption Perceptions Index (CPI) ${ }^{1}$ ranking from $36^{\text {th }}$ position in 2011 to $50^{\text {th }}$ in 2014 (Global Financial Integrity, 2014). ${ }^{2}$

\footnotetext{
${ }^{1}$ Refer to Transparency International; CPI measures the perceived level of public-sector corruption in 183 countries and territories around the world.

${ }^{2}$ Malaysia was ranked as the $53^{\text {rd }}$ in 2013 Transparency International website, 2011 (accessed from https://www.transparency.org/cpi2014/results on 6 March 2015).
} 
When Malaysia gained independence in 1957, corruption was hardly an issue but has grown since the 1970s. Furthermore, as an Islamic country with Muslim leadership, Malaysia is expected to be clean from corruption as Islam strongly forbids and condemns such malpractices. It is mentioned in the Hadith: "God cursed the one who pays a bribe, the one who takes it and the mediator between the two" (Sahih Muslim) ${ }^{3}$ and in the Quran (11:85): “And O my people! Give full measure and weight in justice and reduce not the things that are due to the people, and do not commit mischief in the land, causing corruption.” The question that arises is why corruption continues to grow and in fact, escalating to bigger scales in the country in recent years?

The extant literature on corruption has acknowledged that it is a complex and multifaceted phenomenon, as it exhibits different forms and functions in diverse contexts, with multiple causes and effects (Brooks, Walsh, Lewis and Kim, 2013). Nevertheless, there is mutual agreement that it entails the abuse of public power, roles or resources for private benefit (Amundsen, 1999; Johnston, 2005), which may exist at the interface between public and private sectors (Rose-Ackerman, 1978) or between international actors and host countries (see e.g. Rose-Ackerman 1999; Bayart et al., 1999). One strand of studies in this area is on identifying the root causes and the appropriate preventive measures that can be taken. ${ }^{4}$ Discussion on the causes of corruption, which can be attributed to individuals, organizations, and institutions, has been grouped in the literature as either the demand-side (referring to the taking) or the supply-side (referring to the giving) of corruption (Heimann and Boswell, 1998; Sikka \& Lehman, 2015). This strand of literature further classified the preventive solutions into control (aimed at improving

\footnotetext{
${ }^{3}$ Cited in Islam message of peace, available at https://islammessageofpeace.wordpress.com/2014/04/29/riba-is-haraam-for-the-one-who-takes-it-andthe-one-who-pays-it-and-it-is-haraam-to-help-with-it-in-any-way-whatsoever/

${ }^{4}$ For a good summary and overview of the literature on the definitions, consequences and causes of corruption, see Everett, Neu \& Rahaman (2006), Tanzi (1998) and Andvig, Fjeldstad, Amundsen, Sissener \& Søreide (2000).
} 
legal, electoral, educational and other institutional systems), exit (alternatives or substitutes available to actors in exiting the situation) and voice (respecting a wide array of perspectives, desires, and forms of practical knowledge) strategies (see Everett, Neu \& Rahaman, 2006; 2007). These studies rightly acknowledged that this global problem and its subsequent solution will always be debatable as the field's actors view the problem in different ways due to differences in the "idiomatic, epistemological, ontological and moral correspondences”' (Rose and Miller, 1992; p. 179).

In this paper, we seek to contribute to the debate on corruption using the lens of political power. We argue that the personalisation of power (Slater, 2003) by the political leadership imbued with neoliberalism ideology induced the production of corruption. Using one of the largest financial scandals in a state-owned enterprise during the premiership of Mahathir Mohamad as a case study, we provide evidence on how an aspired autocratic leadership managed to personalised power and weakened the infrastructural apparatus that provides the necessary check and balance. This, in turn, facilitated the production of corruption on both the demand and supply side.

The paper proceeds as follows. In the next section, we discuss the notion of personalisation of power and mechanisms of personalisation that can be utilised in transforming a democratic system into an autocratic regime as well as explain how the adoption of neoliberalism ideology may further facilitate the production of corruption. Section 3 presents the case study and discusses the modus operandi of the production of corruption, as well as the roles of the various actors. The last section concludes the paper with some reflections and suggestions for further research.

\section{Personalisation of power, neoliberalism and the production of corruption}


The fundamental purpose of any democratic institutions is to provide stable patterns of popular representation. According to Mann (1988, p.5), one way this can be achieved is by constraining the chief executive's 'despotic power', referring to the range of actions that an individual leader is empowered to take without routine, institutionalized negotiations with other regime members (i.e. the power to decide). The raison d'etre in authoritarian institutions is to supply a regime with the 'infrastructural power' (i.e. the power to govern) which is necessary if command over potential opposition in civil society and within the multiple layers of the state apparatus itself is to be implemented. In other words, while democratic institutions serve to keep the chief executive in check, authoritarian institutions serve to keep the opponents under wraps (Mann, 1988). According to Slater (2003), in semi democratic regimes, personalisation of power by any aspiring autocrat requires high levels of infiltration into infrastructural powers in order to command the whole country. Three mechanisms that can be utilised by the aspiring autocrat to personalise his/her power include: packing, through commandeering the power of an existing institution for personal purposes; rigging, through the strategic modification of institutional rules and procedures to forestall competition for leadership positions; and circumventing through either the creation of entirely new organizations or demand for existing organizations to take on entirely new tasks which implies the squandering of at least a portion of a regime's institutional inheritance (Slater, 2003; p.91). This process is further made possible in such regimes through the adoption of neoliberalism.

Historically, neoliberalism ideologies as championed by Keynes were associated with the role of the state in constraining the mobility of capital and in redistributing wealth for a more equitable and just society (Sikka, 2015). However, over time, the idea of the control of capital by the state was challenged by Hayek (1944) who argues that 
market prosperity, stability and social justice can be achieved through free market and minimum state intervention while still providing minimum provision to those who cannot earn a living in the market (Tebble, 2010). During the late 1970s and early 1980s, Harvey (2005) observes further expansion of free market competition, mobility of capital and no state intervention in the economic sphere in the name of attaining social efficiency. This rebranding of neoliberalism resulted in total loss of state control over organisations and individuals and enabled competitive beings to indulge in endless pursuit of private gains and in legitimising their activities (Boltanski and Chiapello, 2005).

The embracement of neoliberalism ideologies by western powers is not only confined in their own territories but also exported to other developing countries through foreign direct investments (Sikka, 2015) and other tools deemed necessary for modernising their economies. The neoliberalists have managed to convince the political elites in developing countries "that the system is natural, fair and fundamentally better than any realistic alternative” (Sklair, 1995; p.98), which in turn either directly or indirectly made them to believe in their own inferior socio-political and economic setting as compared to advanced nations. This inferiority complex results in political elites in developing countries to voluntarily embrace the structures and values of their western counterparts, as opposed to other alternatives that may be more suitable in fulfilling local needs, and may also be motivated by the obvious private rewards that can be gained through close relationship with business elites who needed them in order to survive in the competitive market. This symbiotic relationship led to the state becoming nothing more than a façade masking the realities of deeply personalised political relations, clientelism (including nepotism and cronyism), and political corruption (Hope and Chikulo 2000; Chabal and Daloz 1999). Adoption of neoliberalism weakened the distinction between public and private which dominates the politics of some countries, especially in Africa 
and some parts of South-East Asia.

Unlike neoliberalist political leaders in democratic countries who are subject to public scrutiny if their style of reconfiguring the resources may have negative impact on society, their counterparts in developing countries may use mechanisms of personalisation of power to silence their opponents and critics especially when there is a lack or weakened infrastructural power (public and legal institutions).

Another outcome of the adoption of neoliberalism is crony capitalism, a system where significant parts of the economy are controlled by the government and political elites who will use the power of the state to make decisions in the best interests of a particular set of well-connected businesses, rather than in the best interest of the market as a whole (Girling, 1997; Chang, 1998; Krugman, 1998; Wade, 1998; Haber, 2002). Harvey (2005) succinctly defined crony capitalism as corrupt relationships between the state and businesses. In the extreme case, crony capitalism can degenerate into corruption when contracts and appointments are awarded to families and friends (nepotism) without merit or transparent procurement process. Similarly, crony capitalism, assists in generating plutocracy, whereby a small minority of the wealthiest citizens rule the country (Phillips, 2004) or kleptocracy, where the political elites seek to increase their personal wealth often in the pretence of providing honest service to the society i.e. corruption rule by theft (Bush, 2006). While both plutocracy and kleptocracy seem to favour the political elites, their closeness with business corporations including accounting firms, intensify the production of corruption.

\subsection{The Malaysian context}


Malaysian politics has been dominated by the National Front or Barisan Nasional (BN) ${ }^{5}$ communal coalition party, with administration of the country being in the hands of the leader of the United Malays National Organisation (UMNO) political party. The country has been under six premierships ${ }^{6}$ including the present one. However, it was Mahathir's twenty two years of premiership that has significantly transformed Malaysian political and socio-economic landscape that persists till the present day. According to Gomez and Jomo (1999), the neoliberal policies and discourses that assist in wealth accumulation and concentration through political patronage intensified during Mahathir's administration. When he came into power in $1981^{7}$, he was inspired by the success of the four Asian Tigers or Asian Dragons ${ }^{8}$ that had developed into advanced and highincome economies through rapid industrialisation. Hence, through his ‘Look East’ policy, Mahathir utilized greater state intervention to promote heavy industrialization to emulate Japan and South Korea. The state-sponsored and HICOM-led program of heavy industrialization was mostly implemented in joint-ventures with Japanese firms, and the HICOM enterprises were primarily financed by heavy borrowing from the Japanese government at very low interest rates (Jomo, 2003).

In 1984, Mahathir appointed Daim Zainuddin, a successful businessman and a close friend, as his economic advisor. Under the Malaysian Incorporation Policy, significant economic policy reversals which include regressive fiscal (tax and spending) reforms,

\footnotetext{
${ }^{5}$ BN or the National Front Party was formed in 1973, replacing the Alliance Party which was formed in 1957. It consists of three communal political parties: the Malaysian Chinese Association (MCA), Malaysian Indian Congress (MIC) and the secular United Malays National Organisation (UMNO). There two political opposition parties before 1998 are the Pan-Malaysian Islamic Party (PAS) and the Democratic Action Party (DAP).

${ }^{6}$ Tunku Abdul Rahman (1957-1969), Abdul Razak (1969-1976), Hussein Onn (1976-1981), Mahathir Mohammad (1981-2003), Abdullah Badawi (2003-2009) and Najib Razak (2009 to present).

${ }^{7}$ His ascend to power was just after Margaret Thatcher was elected Prime Minister of Britain in 1979 and Ronald Reagan was elected President of the United States in 1980, both of whom are known to be the champions of neoliberalism doctrine.

${ }^{8}$ This term is used to refer to the highly free and developed economies of Hong Kong, Singapore, South Korea, and Taiwan.
} 
more stringent public expenditure cuts, privatization, deregulation, and financial liberalization were implemented (Jomo, 2003). This policy and the earlier National Economic Policy (NEP), ${ }^{9}$ succeeded in creating a small group of super-rich bumiputra (indigenous group) class but failed to achieve its main objective of reducing economic inequalities among the indigenous group; in fact it actually widened social inequality (Gomez and Jomo, 1999). Other reports highlighted that Malaysia’s level of inequality was among the highest reported in the region, with a Gini coefficient ${ }^{10}$ of 0.49 during 2000 (Netto, 2004), while at the same time the rich are getting richer in Malaysia. The widespread poverty in Malay dominated states caused some UMNO supporters to question the policies that focused on privatisation and heavy industries run by favoured businessmen (Saw and Kesavapany, 2006), including those with family and friendship ties. To ease the friction, the ruling party created a 'new middle-class' Malay professionals (Rahman, 2002) and this frustrated some of the Malay elite groups who monopolised most of the country's concessions or rents, causing them to switch their loyalty from UMNO to the opposition party, the Parti Keadilan Rakyat (Malaysian Justice Party) led by Anwar Ibrahim. ${ }^{11}$

From 1985 onwards, business regulation for inter-ethnic redistribution purposes as required under the NEP and the Industrial Coordination Act 1975, was abandoned. This further intensification of political patronage with certain bumiputra and non-bumiputra

\footnotetext{
${ }^{9}$ Before 1969, the ruling party adopted a liberal agenda with minimal state intervention which resulted in excessive accumulation of wealth by the Chinese ethnic group. Frustrated with unequal wealth distribution coupled with violation of Islamic principles in social and political policies, sparked the May 13 ethnic riot in 1969 (Hooker and Othman, 2003). Following the riot, Abdul Razak introduced the New Economic Policy (NEP), a twenty-year social re-engineering and affirmative action plan to eliminate the identification with economic function as well as to increase enterprise ownership by the bumiputra (indigenous group).

${ }^{10}$ Gini coefficient: a measurement used to evaluate income inequality where 0 indicates perfect equality and 1.0 indicates perfect inequality (Worldpress.org).

${ }^{11}$ He was the former Finance Minister, deputy PM and UMNO deputy president who was punished and removed from government office in 1998 and imprisoned by Mahathir for sexual impropriety allegations and other corruption charges. He is currently serving a 5 year-term after being implicated again for sodomy charge under PM Najib’s administration.
} 
businessmen do not only brought mutual benefits to the two groups but also seen as important for the development of business interest (Gomez and Jomo, 1999). When the first recession hit in 1985-1987, many Malaysian corporations, especially those associated with the regime’s 'cronies', were very highly leveraged but they were protected and supported through government bailouts to ensure that Mahathir achieved his goals of making Malaysia a fully-developed industrial country through his Vision 2020 policy (Gomez and Jomo, 1999).

When the 1997 financial crisis erupted, Mahathir was once again anxious to protect and organize bail-outs for the cronies, which led critics to charge that the regime's cronies were doubly blessed - first by benefiting from privatization in the 1980s, and then by walking away unscathed from their debts and liabilities through bail-outs using public funds (Jomo, 2003). Mahathir also has an obsession for mega-projects and it was during his time that the Petronas Twin Towers, KLIA, Putrajaya and Sepang Grand Prix Circuit were developed. Critics at that time expressed doubts that the country's resources had been put to the best and most productive use and some economists were concerned on the financial implications (huge government debts) and depleted natural resources for the next generation of Malaysians (Netto, 1999) as a result of these mega ventures.

In short, under Mahathir, Malaysia experienced 20 years of privatizing profits and profitable assets and socializing of losses and liabilities (Jomo, 2003). The perpetrators were not made accountable and overly protected which may be attributed to the personalization of power by the leadership. Leong (1992, p. 243) commented that “... under the Mahathir administration, the Cabinet is no longer used as a forum, but rather as a rubber-stamp institution that gives legitimacy to government policies.” Similarly, Leigh (2001, p.7) succinctly commented:

“...the most enduring consequence of the Mahathir era has been a deliberate and decisive weakening of Malaysia's institutions, including the judiciary, the royalty, 
the independent civil service, the parliament, the electoral system and....The institutions of governance are much weaker, and rulership has been personalized.”

The personalisation of power was achieved by packing the most important posts in the cabinet and institutional infrastructure with loyalists, and he himself subsuming another two vital posts, home minister and finance minister in 1998. Rigging of the political party's procedures facilitated his personal domination of the hegemonic political organization (Slater, 2003) and in centralising the ruling party's power in a few executives' hands (Gomez, 2004; Saw and Kesavapany, 2006). Circumvention was used in silencing and later ousting the then Finance Minister, Anwar Ibrahim, who had opposed to bail-outs using public funds. ${ }^{12}$ He appointed Daim as the 'virtual finance minister' (Erickson and Shameen, 1998) and also allowed himself direct control over a variety of discretionary funds to prepare strategic bailouts for his key allies in the corporate sector (Slater, 2003).

In the next section we present a case as evidence on how neoliberalism ideology and personalisation of power by a political leader facilitated the production of corruption in a state-owned enterprise. The research was conducted through scrutinizing newspaper articles, website commentaries, books and journal articles related to the company and major actors. Although there are other scandals involving state-owned companies in Malaysia, we chose Perwaja Steel as our case as it was one of the largest scandals at a time when personalisation of power had just started to develop.

\section{Production of corruption in Perwaja Steel}

\footnotetext{
${ }^{12}$ Mahathir and Daim instructed the Finance Minister, Anwar Ibrahim to suspend KLSE rules to allow the leading crony UEM-Renong conglomerate a bailout. That move caused the stock market capitalization to fall by RM 70 billion, or 20 percent, in three days in November 1997 (Jomo, 2003). These policy divergences between Mahathir and Anwar had caused the latter a heavy price. In 1998, Anwar was imprisoned for five years on sodomy allegation.
} 


\subsection{Company background}

Perwaja Terengganu was formed on 22 April 1982 with a paid up capital of RM 250

million as a joint-venture between the government agency, Heavy Industries Corporation of Malaysia (Hicom Ltd) and Nippon Steel Corp. ${ }^{13}$ The project was meant to be the crowning jewel of the industrialization drive under Mahathir's Look East policy. The Japanese company built a billet-making plant and a direct-reduction facility to smelt ore into hot briquetted iron based on a new technology. The direct-reduction plant never functioned properly and by 1986, the joint-venture project accumulated losses of RM 131 million. This was attributed to management problems and appreciation of the Japanese yen which affected its interest payments on a yen loan totaling RM 815 million (The Malay Mail, 10 February 2004). In 1987, Nippon Steel gave up its 30 percent stake in the company and Hicom was stripped of its 51 percent stake, ending with the Malaysian government owning $81 \%$ of Perwaja Terengganu's equity and $19 \%$ held by the Terengganu state government. In 1987, Mahathir handpicked his trusted associate, Eric Chia, ${ }^{14}$ to spend six months in the company to report why the project was failing. In 1988 , Eric was formally appointed as the managing director of Perwaja Teregganu and during this period, more than 10 proposals were received by the government to turn the RM 1.2 billion plant into a profitable venture but it was left to become insolvent in 1988 .

Based on a 10-year plan and with fresh capital from government funding and commercial loans from Bank Bumiputra ${ }^{15}$ (RM 860 million) and the Employee Provident Fund (EPF-RM 130 million), a new company, Perwaja Steel was set up in 1989. Eric and

\footnotetext{
${ }^{13}$ Hicom owned 51\%, Nippon 30\% and Terengganu state government 19\%.

${ }^{14} \mathrm{He}$ is a Singapore-born Chinese entrepreneur who became a successful and prominent businessman in Malaysia. He came to Malaysia at the age of 23 and managed United Motor Works (UMW) set up by his father. The company became the country's largest engineering group. He established strong friendship with Mahathir who supported his business through major government contracts. In 1987, he helped rescue a haulage and logistic company set up by Mahathir. He was nicknamed Mr Fixit as he is often called upon to help the political elites when their businesses are in trouble (The Staronline, June 25, 2008).

${ }^{15}$ UMNO is a major shareholder of the bank.
} 
his board of directors, who included representatives from the Finance Ministry, were tasked with rehabilitating the project. In 1991, the company recorded its first accounting profit and Mahathir used the event to silence critics on his aggressive mega projects adventure. In 1995, Eric resigned abruptly from the company ${ }^{16}$ and a year later, a pre-tax loss of RM 376.54 million was reported, claimed to be due to the expansion project involving the building of a rolling mill. Despite the loss, the company managed to secure a second syndicated loan of RM 600 million approved by EPF in 1996. When Eric left the company in 1995, it had accumulated RM 10 billion in debts and losses, involving current liabilities of RM 9.26 million, long-term loans of RM 6.013 billion, and losses amounting to RM 2.985 billion (News Straits Times, 28 March 2003). Table 1 presents the status of the company’s financial position in 1995.

\section{Table 1 Summary of Perwaja Finances in 1995}

\begin{tabular}{|c|c|c|}
\hline \multicolumn{3}{|l|}{ Indebted } \\
\hline Major Malaysian lenders to Perwaja & RM million & Yr of Maturity \\
\hline Bumiputra Merchant Bankers (syndicated loan) & 135 & 2003 \\
\hline Arab-Malaysian Merchant Bank Bhd. & 430 & 2004 \\
\hline Arab-Malaysian Merchant Bank Bhd. & 270 & 2007 \\
\hline Arab-Malaysian Merchant Bank Bhd. & 600 & 2000 \\
\hline Arab-Malaysian Merchant Bank Bhd. & 600 & 2002 \\
\hline Employees Provident Fund & 710 & 2001 \\
\hline \multicolumn{3}{|l|}{ Bills to pay } \\
\hline \multicolumn{3}{|l|}{ Perwaja by the numbers: } \\
\hline & End of 1998 & End of 1997 \\
\hline Direct loans owed to the government & RM 4,015m & RM 3,174m \\
\hline Outstanding loans guaranteed by government (Local \& Foreign) & RM 5,122m & RM 5,682m \\
\hline \multicolumn{3}{|l|}{ Major Foreign Lenders to Perwaja } \\
\hline & RM million & Yr of Maturity \\
\hline IBJ Leasing Services (Panama) Inc. & 199.3 & 2003 \\
\hline Standard Chartered Bank (Labuan) & 1,520 & 2002 \\
\hline Japanese Banking Consortium & 685.5 & 2003 \\
\hline
\end{tabular}

Source: Lopez (2000) based on Malaysian government sources.

\footnotetext{
${ }^{16}$ In an interview after being released from conviction, he revealed that he had received a letter from a senior official asking him to resign due to ill health.
} 
Anwar Ibrahim, the former Finance Minister, instructed an independent audit firm, Coopers and Lybrand to examine Perwaja Terengganu's 1988 insolvency status. Following the report received from the audit firm, Anwar disclosed in parliament that the actual loss was RM 2.9 billion and made a police report. A government probe order was then issued on 10 April 1996 and the Anti-Corruption Agency (ACA, now known as Malaysian Anti-Corruption Commission (MACC)) started investigating the company's audited report for possible malpractices which had contributed to the loss. Furthermore, the new management of Perwaja Steel prepared an internal report where it alleged among others, the following: inaccurate accounting records, unauthorised contracts amounting to hundreds of millions of ringgit, misappropriation of funds, dubious maintenance contracts amounting to RM 292 million (including a contract amount of RM 200,000 per month to a company for gardening, cleaning and vehicle maintenance), and award of RM 957 million contract to companies of a long time associate of Eric Chia (WTF, 15 December 2011).

On 16 June 1997, Perwaja Steel was handed over to two cronies: Abu Sahid of Maju Holdings, who took a 51\% stake saw it as an opportunity to be known as a steel man, and the Pheng family of Kinsteel who took over the remaining to thwart threat to their own steel operations business. In 2008, Perwaja Holdings was listed on the main board of Bursa Malaysia and Perwaja Steel became its 100\% subsidiary. EPF filed suit against Perwaja Steel for RM 4.5 billion and it went into receivership in December 2014. Table 2 illustrates the chronology of the emergence \& demise of Perwaja Steel.

Table 2 Chronology of the Emergence \& Demise of Perwaja Steel 


\begin{tabular}{|c|c|c|c|c|c|c|}
\hline $\begin{array}{l}\frac{1982}{-}-\mathbf{-}-\mathbf{-} \\
\text { Perwaja } \\
\text { Terengganu }\end{array}$ & \begin{tabular}{l}
1987 \& 1988 \\
\hdashline$-\geq-1-$ \\
Perwaja \\
Terengganu
\end{tabular} & $\begin{array}{l}\mathbf{1 9 8 9} \\
\frac{\mathbf{P}}{\text { Perwaja Steel }} \mathbf{-} \\
\text { MD -Eric } \\
\text { Chia }\end{array}$ & $\begin{array}{l}1995 \& 1996 \\
\frac{-1}{\text { Perwaja Steel }}- \\
\text { Eric Chia } \\
\text { resigned in } \\
1995\end{array}$ & $\begin{array}{l}1997 \\
\text { Perwaja Steel }\end{array}$ & $\begin{array}{l}\mathbf{2 0 0 8} \\
\text { Perwaja Steel } \\
\text { became } 100 \% \\
\text { subsidiary of } \\
\text { Perwaja Bhd }\end{array}$ & $\begin{array}{l}2014 \\
\text { Perwaja } \\
\text { Steel went } \\
\text { into } \\
\text { receivership }\end{array}$ \\
\hline $\begin{array}{l}\text { Hicom } \\
\text { (51\%), } \\
\text { Nippon } \\
\text { (30\%) \& } \\
\text { Terengganu } \\
\text { state govt. } \\
(19 \%) \\
\end{array}$ & $\begin{array}{l}\text { Federal govt. } \\
\text { (81\%) \& } \\
\text { Terengganu } \\
\text { state govt. } \\
(19 \%)\end{array}$ & $\begin{array}{l}\text { Federal govt. } \\
(81 \%) \text { \& } \\
\text { Terengganu } \\
\text { state govt. } \\
(19 \%)\end{array}$ & $\begin{array}{l}\text { Federal govt. } \\
\text { (81\%) \& } \\
\text { Terengganu } \\
\text { state govt. } \\
(19 \%)\end{array}$ & $\begin{array}{l}\text { Maju } \\
\text { Holdings } \\
(51 \%) \& \\
\text { Kinsteel } \\
(49 \%)\end{array}$ & $\begin{array}{l}\text { Kinsteel } \\
\text { owns 37\% of } \\
\text { Perwaja Bhd }\end{array}$ & \\
\hline $\begin{array}{l}\text { RM 250m } \\
\text { paid-up } \\
\text { capital \& } \\
\text { RM 500m } \\
\text { loan from } \\
\text { Export- } \\
\text { Import } \\
\text { Bank of } \\
\text { Japan }\end{array}$ & $\begin{array}{l}\text { Reported } \\
\text { loss of RM } \\
131 \mathrm{~m} \text { in } \\
1986 \& \text { in } \\
1988 \\
\text { reported } \\
\text { total } \\
\text { accumulated } \\
\text { loss of RM } \\
1.2 b \text { \& } \\
\text { became } \\
\text { insolvent in } \\
1988\end{array}$ & $\begin{array}{l}\text { New } \\
\text { company set } \\
\text { up through } \\
\text { govt. funding } \\
\text { \& loans from } \\
\text { Bank } \\
\text { Bumiputra } \\
\text { (RM860 m) } \\
\text { and EPF } \\
\text { (RM130 } \\
\text { million) }\end{array}$ & $\begin{array}{l}\text { Reported pre- } \\
\text { tax loss of RM } \\
376.54 \mathrm{~m} \text { in } \\
\text { 1996. Secured } \\
\text { funding of RM } \\
600 \mathrm{~m} \text { loan } \\
\text { from EPF. } \\
\text { Total } \\
\text { accumulated } \\
\text { losses of RM } \\
\text { 2.5b, long-term } \\
\text { loans of RM 6b } \\
\text { \& current } \\
\text { liabilities of } \\
\text { RM 1b }\end{array}$ & & $\begin{array}{l}\text { Perwaja Bhd } \\
\text { listed on } \\
\text { main board of } \\
\text { Bursa } \\
\text { Malaysia }\end{array}$ & $\begin{array}{l}\text { EPF filed } \\
\text { suit for RM } \\
4.5 b\end{array}$ \\
\hline
\end{tabular}

Mahathir’s neoliberalism ideology of Malaysia Incorporation (Jomo, 2003) made him pursue an aggressive industrialization and privatisation agenda with the rhetoric of matching the other Asian Tigers regardless of the impact on the democratic process. Despite the project showing many signs of failure, he kept injecting more public funds into the 'pet' project as he perceive it as too important to fail to safe his ego and also to ward off increasing criticisms from his opponents. He turned to neoliberalist cronies for advice and support and in return promised protecting their interests by utilizing the infrastructural power. This supports the arguments by Boltanski and Chiapello (2005) and Sikka (2015) that neoliberalism ideology legitimises competitive beings to indulge in endless pursuit as sign of success.

\subsection{Deployment of power and production of corruption}


Although the ACA's probe on Perwaja Steel started in 1996, no one had been implicated until $9^{\text {th }}$ October 2004, when Eric Chia was arrested and charged for criminal breach of trust during the premiership of Abdullah Badawi. Eric was alleged to have dishonestly authorised payment of RM 76.4 million to the account of Frilsham Enterprise Incorporated (Frilsham) with the American Express Bank Ltd in Hong Kong for technical assistance agreement (TAA) provided to the Perwaja plant by a Japanese company, NKK Corporation, when in fact no such payments were due to these companies. He was also alleged to have instructed payment of the same amount without the approval of the board of directors nor the tendering committee of the Perwaja Rolling Mill and Development. The offence was alleged to have been committed in his capacity as the managing director of Perwaja Steel between 4th November 1993 and 22nd February 1994.

The ACA's failure to wrap up its investigation sooner and nab the perpetrators responsible for the RM 10 billion staggering losses at Perwaja Steel has been criticized by members of both the opposition and the ruling National Front $(\mathrm{BN})$ coalition. Unlike in most countries, the ACA was under the Prime Minister's Department which thus diminishes its power to act independently since investigation of the case began during Mahathir's premiership. The timing of the arrest and allegation also raised further questions as Eric's detention was not related to the huge debt and losses suffered by the company to bring the perpetrators to justice but rather a political ploy ahead of the 2004 general election.

Fig. 1. Deployment of Power and Production of Corruption

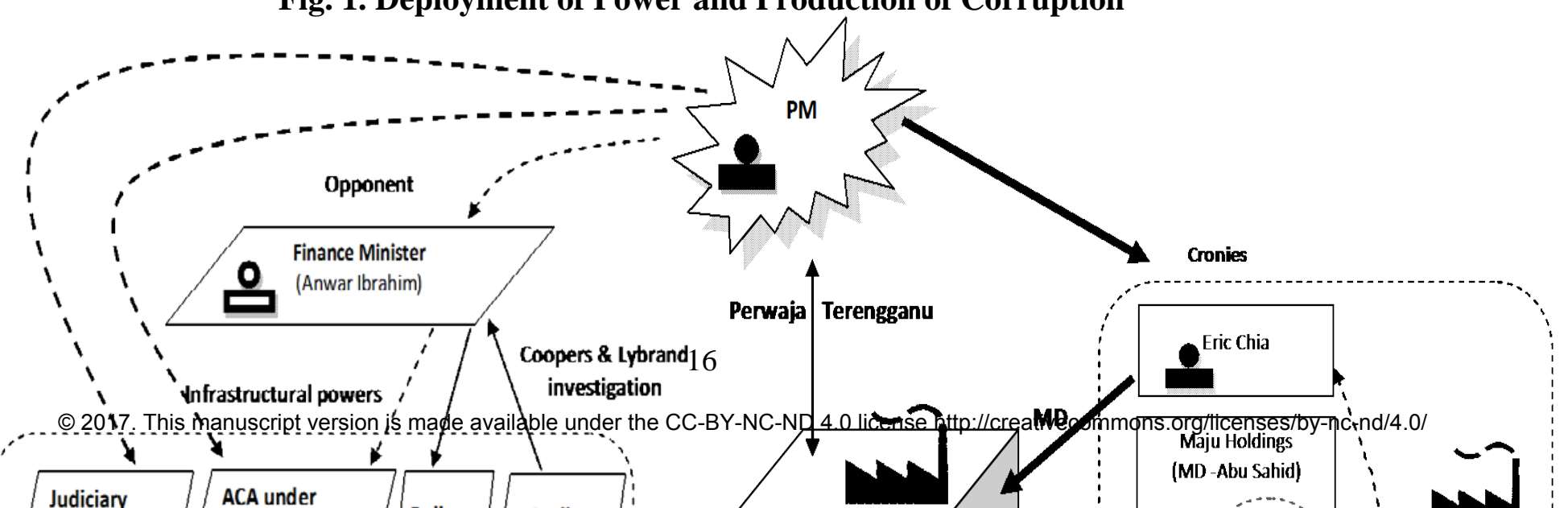


This suggests that Mahathir has succeeded in personalising his power by diverting decision-making authority on major policy issues to the Prime Minister's Department through utilising the packing and circumventing strategies in the case of the ACA and utilising the rigging strategy in determining his successors (i.e. Abdullah Badawi \& also the current PM, Najib Razak) to ensure that he will not be implicated. During the court proceedings, the weak internal control system and the working of a covert power became more apparent. Figure 1 illustrates the main actors and their roles in the case.

The former senior group general manager, Ahmad Zaini, in his comments on the case stated that although the TAA was meant to be free, the payment was made to Frilsham Enterprise’s account in the American Express Bank in Hong Kong following 
Eric Chia’s approval (News Straits Times, 18 September 2004). In his financial report, Ahmad Zaini went on to state that the general manager of NKK Corporation, N. Otani, had confirmed in writing in a letter dated 11 October 1995 that Frilsham was not its associate company, hence NKK's Otani did not sign any payment request letter but this letter was not produced in court. On the contrary, Akram Che Ayub, the former group senior operations manager, stated that the TAA was not free and that the request for payments should be staggered rather than paid in one lump sum. A request letter for the payment bearing the signature of Otani dated 17 February 1994 was confirmed by Akram to be different from that on the TAA and the addendum (News Straits Times, 14 August 2004). A letter instructing one lump sum payment to be remitted to Frislham's account with the American Express Bank Ltd in Hong Kong had been made through Bank Bumiputera in Malaysia on 22 February 1994 (The Malay Mail, 14 August 2004). Lim Chaing Cheah, a former corporate director who instructed the payment, stated that he was ordered by Eric to proceed with it despite the absence of any supporting documents to justify the said payment. Lim further pointed out that it was customary in the company that all payments ${ }^{17}$ made should first be authorised by Eric and countersigned by him. Lim said:

"For example when a request for payment comes from overseas, we notify the managing director's people. Once approval is given, we get the finance and accounting department to process it" (The Malay Mail, 3 August 2004).

Interestingly, the demised Arthur Andersen, the company’s external auditor, had all along issued 'unqualified' audit report until the company became insolvent. The clean audit report on the company’s financial position had been presented to the board of directors

\footnotetext{
${ }^{17}$ Payments for projects, constructions of plants, purchasing of raw materials and services that include technological consultancy (The Malay Mail, 3 August 2004).
} 
on 31 March 1994 and was approved during the annual general meeting (The Malay Mail, 3 August 2004). The responsibilities of Perwaja Steel's corporate directors surpassed four pertinent departments viz. finance and accounting, administrative, corporate banking and management information system (The Malay Mail, 3 August 2004), hence suggesting weak internal control system and poor corporate governance. The fact that the external auditor failed to probe further on the missing document suggests either incompetency or some involvement in the malpractice.

However, a pertinent question in all this is the rationale of a Japanese company (NKK) requesting payments for its services to be made to the bank account of its associate company (Frilsham) in Hong Kong rather than directly to it. The scandal worsened when NKK was later found to be non-existent (The Malay Mail, 10 February, 2004) and that Frilsham's account at American Express Bank in Hong Kong was closed on $28^{\text {th }}$ July 1994 i.e. about five months after the RM 76.4 million was paid into the account (News Straits Times, 17 September 2004). Australasian Business Intelligence (23 May 2002) reported that the payment appeared to have benefitted Sakyo Corporation, a company associated with Shahril, the son of Shamsuddin Abdul Kadir, ${ }^{18}$ a crony of Mahathir who was also closely linked to Eric Chia. While the use of Frilsham as an intermediary company or SPV may be deemed to be a cover up, this was made possible as Hong Kong is considered as one of the most lenient countries with loose regulations. In other words, the production of corrupt transactions and the choice of a safe haven to conceal the fraudulent act were the consequence of the adopted neoliberalism ideology, facilitated by the personalization of power that has weakened the various check and balance infrastructures in Malaysia.

\footnotetext{
${ }^{18}$ He was a former engineer with Malaysian Telecommunication Department who retired in 1971 and started a family control company, Sapura Holdings, which bought UMW from Eric Chia.
} 
The court proceedings further revealed of a covert power in action. Eric, in a letter addressed to the Chairman of Perwaja Steel, Zainal Abidin Sulong, in the minutes of the board's meeting held on 30 March 1996, clearly stated that: (1) he was answerable only to the Prime Minister (PM-Mahathir); (2) he was mandated by the PM to operate Perwaja as if it belonged to him; (3) he implemented projects only after the PM had granted approval; (4) he received no salary or benefits from Perwaja during his service; and (5) his service as managing director in Perwaja is determined by the PM. This clearly indicates Mahathir's success in creating loyalist cronies like Eric who is willing to implicate himself rather than to risk his ‘friendship’ with Mahathir.

According to the minutes of the board of directors meeting on 4 July 1993, it was reported that Eric informed the board that he had met Anwar Ibrahim, the Finance Minister the day before (i.e. 3 July 1993) who agreed to waive a circular ${ }^{19}$ dated 6 August 1985 which requires all companies under the government to get approval for any tenders amounting RM 15 million and above. Eric also suggested for the formation of a tendering committee ${ }^{20}$ comprising of himself as the chairman together with the other two directors, Nik Mohamad Affandi and Zubir Embong. The board unanimously approved the procedure for the purchases and awards of contracts as directed by the Ministry of Finance (MOF) and proposal for the tendering committee. The board's chairman, Zainal Abidin Sulong, further reported that the board also approved Eric to conclude purchases and contracts without referring to the tendering committee for consumable goods like electrodes, scrap, iron ore, lubricants, etc., and any contracts of RM 5 million and below. Ironically, another former board director who was also the MOF's representative on the board, Nik Mohd Affandi Nik Yusoff, told the court that the MOF had never forced the

\footnotetext{
${ }^{19}$ The Circular: is a strict financial guideline which requires companies in which the Government owns at least 51\% equity, to keep the MOF informed on projects, tenders, and purchases at the initial stage of negotiations.

20 The tender committee needs to approve all contracts or purchase of RM 15 million or above.
} 
company to activate its tendering committee and he also disagreed with some parts of the minutes of meeting which stated that the MOF had agreed to exempt the company from seeking approval for purchases and contracts of RM 15 million and above. These are not the comments of equal parties to a commercial transaction, hence implying a calculated paternalism. Furthermore, evidence shows all these liberal gestures were being carefully recorded as part of an accounting process directed at securing contracts. In a nutshell, Mahathir has not only managed to pack the company with loyalists but more importantly, to circumvent the infrastructural power of the MOF by frustrating the rules in place. The establishment of the ad hoc National Economic Action Council, headed by Mahathir's closest ally, Daim, was further evidence of circumvention of Anwar's power in restraining the usage of public funds to rescue and support cronies in trouble.

When the Anti-Corruption Agency’s (ACA) investigating officer, Han Chee Rull, was asked by the court if he had (1) obtained recorded statement from the PM, (2) seen the correspondence between Eric Chia and the PM, (3) knew about the PM's visit to the NKK's plant in Japan before the TAA was signed, and (4) Eric Chia's three suits that had been filed against NKK Corporation, Lim Guan Eng and The Malay Mail, he confirmed that no recorded statement was taken from Mahathir and that he was unaware of the other three issues. The admission of unawareness on the many incidents related to the accused Eric Chia by the ACA investigating officer responsible in handling the case, implied some form of subjugation and control of the course of justice by Mahathir. As mentioned earlier, the packing and circumvention strategies by locating the ACA under the PM's Department constrain the effectiveness of the agency to act independently and to remain subservient to the leadership.

Rais Yatim, the then Minister in the PM's Department, reported that the Swiss Government was prepared to cooperate with the Malaysian authorities in probing the 
missing Perwaja Steel’s money in Swiss bank accounts (The Malay Mail, 3 August 2004) and that the ACA, under the Mutual Assistance in Criminal Matters Bill 2002, can make an official request to freeze the bank accounts of those allegedly involved in the scandal. He further reported that 3 senior ACA officers went to Zurich and Japan to find the last piece of evidence to wrap up the investigations. However, the ACA officers claimed that they did not get cooperation from the Zurich bank and the Japanese banking authorities, hence the vital evidence could not be sought. Rais's comments on Mahathir's relative invisibility in the case ensured he was able to maintain friendly 'relations' with the powerful leader of the ruling party. The PM's office is packed with loyalists and it serves as the nerve centre in rewarding loyalists and punishing opponents.

In 2007, Eric was acquitted of the charges by the Judge, Akhtar Tahir, who said that the prosecution had failed to establish a prima facie case against Eric on two grounds. Firstly, failure to call two material witnesses, former secretary of Perwaja Steel, Durai Rajasingam, and the five Japanese witnesses including the director of NKK Corporation, N. Otani. The Judge raised his concerns on the uncalled witnesses respectively, saying:

"...Yet the prosecution never called him [Rajasingam]. The question is why? I see nothing to say that he would be a hostile witness or give evidence against them.........I wonder whether it was the Japanese witnesses who were reluctant or the prosecution was the one reluctant to bring them here.." (Thestaronline, 27 June 2007).

Secondly, the conflicts in the tendering documents - the prosecution insisted that the TAA was free but when tendering its document at the trial, they stated the agreements would be effective upon receiving the first payment while NKK Corporation's document stated the amount should be paid in one lump sum. The release of Eric Chia from all the criminal breach of trust charges on 26 June 2007 (Thestaronline, 27 June 2007) provided some form of comfort for the other perpetrators who have links with political patronage 
as they will escape the law. The judiciary was one of the earliest (since 1988) institutions packed by Mahathir in order to enhance his infrastructural power and Eric's trial was seen by critics as another 'wayang' (theatrical act).

The Perwaja Steel fraud case which dragged for 11 years (from 1996 until 2007) was indeed one of the country's longest investigations. The involvement of foreign institutions and powerful individuals was blamed for the case being dragged for so long. While this might be true due to the nature of the case, it may also be seen as a tactic used by the relevant parties as a massive cover up exercise hoping that people will forget about it with the passing of time (Grenfell, 1979). Table 3 summarises the chronology of events on the role of Mahathir and his cronies in the production of corruption and how he used the state apparatus and his loyal cronies and other political elites to ensure he was never implicated nor referred to in the Perwaja Steel fiasco.

Table 3 Chronology of events of the Perwaja debacle

\begin{tabular}{lll}
\hline Year & Events & $\begin{array}{l}\text { Neoliberalism \& Personalisation of } \\
\text { power by an autocrat }\end{array}$ \\
\hline 1982 & $\begin{array}{l}\text { Perwaja Terengganu was established as a } \\
\text { joint venture between the government and } \\
\text { Nippon Steel Corp of Japan in the east } \\
\text { coast of Malaysia although steel was } \\
\text { consumed in huge volumes in the west } \\
\text { coast, which clearly is a recipe for disaster. }\end{array}$ & $\begin{array}{l}\text { Mahathir justified his decision by } \\
\text { claiming that he was taking } \\
\text { industrialisation to the east coast of } \\
\text { Malaysia to help develop the state. }\end{array}$ \\
& $\begin{array}{l}\text { Perwaja Terengganu accumulated losses of } \\
\text { RM 131 million. }\end{array}$ & $\begin{array}{l}\text { Mahathir blamed it on appreciation of the } \\
\text { yen and not on poor management skills }\end{array}$
\end{tabular}


1987
Eric Chia mandated to investigate why the project failed.

Perwaja Terengganu went into solvency.

Perwaja Steel was established and Eric was appointed as managing director.

Perwaja Steel recorded its first profit.

Eric Chia resigned from Perwaja Steel.

Perwaja Steel reported a pre-tax loss of RM 376.54 million.

Anwar Ibrahim disclosed in parliament Perwaja's actual loss to be RM2.9 billion based on the report by Coopers \& Lybrand who was tasked to investigate Perwaja Terengganu's insolvency status.

Maju Holdings Sdn Bhd bought 51\% stake in Perwaja Steel.

Anwar Ibrahim was expelled from the government as he was against injecting public funds on failing projects and those that do not benefit society.

Eric was arrested and charged of criminal breach of trust involving RM 76.4 million.

Eric was acquitted by the judge. of his inexperienced cronies in the steel sector.

Mahathir used Eric as his Mr Fixit to help rescue his failing pet project.

Mahathir did not want to admit failure of his project, hence rejected proposals to turn around the company to profitable venture.

Mahathir used one of the state agencies, EPF to provide syndicated loan to help Eric managed the new company. Representatives from MOF sat on the board of the company.

Mahathir used the event to justify that his action in appointing Eric to manage his new project was correct to ward off criticisms on his mega projects.

Mahathir ordered Eric to resign.

Mahathir used EPF for the second time to provide syndicated loan.

Anwar instructed ACA to begin investigation on the company's audited report by Arthur Andersen for possible malpractices and fraud that have contributed to the loss.

Mahathir helped another of his Malay crony, Abu Sahid to acquire the business and only in 2003 the deal was inked and for the company to assume control.

Mahathir used the judiciary institution to imprison Anwar for sodomy allegation and other corruption charges.

Abdullah Badawi who superseded Mahathir used Eric's detention as a political ploy ahead of the 2004's general election rather than actually bringing the culprit to justice.

The prosecution team failed to bring the key witnesses and produced conflicting documents causing the case to be dropped.

\section{Reflections and conclusion}

Combating corruption on both the demand and supply side requires understanding of the context and logic of the actors conducting the affairs in modern societies. In developing 
countries, economic policies and actions are often in the hands of the political elites and the doctrine of neoliberalism has been a convenient vehicle in legitimising their exercise of power in turning the state's assets into private enterprises and in deregulating economic activities, as well as in empowering themselves and their cronies in defending their decisions and outcomes. The main criticism on the symbiotic relationship between the political elites and business cronies is the excessive misuse of power to the degree that it corrupts the economic and political principles of public service (Sikka, 2008; Bakre, 2008). Hence, any effort at curbing corruption requires scrutiny of the political ambition and democratic spirit of the 'tone at the top'. When a country is allowed to be run by an increasingly authoritarian personality without constraints on the despotic power, then the country's institutional infrastructure that provides the check and balance may be weakened by the aspiring autocrat through various means of personalisation of power (Slater, 2003).

We demonstrate, using Perwaja Steel as a case study, how a political leader's form of neoliberalism ideology helped him pursue his aggressive industrialization agenda by turning to his cronies and political loyalists to help realize his ambitions and visions. He facilitated political elites to form a small interlocking group to accumulate wealth either individually or collectively. Such interlocking state cannot be maintained in competitive market but when political elites and crony capitalists are entwined, then corrupt and incompetent political elites can maintain the small-hub network by colluding through the awards of tenders or projects within their networks. More importantly, we show how personalization of power through the strategies of packing, rigging and circumventing have weakened the institutional infrastructure such as the judiciary, anticorruption agencies, and police, that provides the check and balance in protecting public interest. 
The nature of fraudulent in a state-owned company is understandably different than in public or family owned business. The failure and scandals of state-owned companies in Malaysia have escalated since the 1980s (Malaysian Airlines, Port Klang Free Zone, etc.) and this can be attributed to the 'bossism' political leadership and the control of the economic machinery. The latest scandal in 2015 is the $1 \mathrm{MDB}$, a sovereign wealth fund set up in 2009 by the current Prime Minister, Najib. All these scandals share the same modus operandi and if the root of the problem i.e. the autocratic leadership is not tackled, then corruption in the country will continue.

Our study is not without limitations. Firstly, we present an in-depth analysis of only one case study of a failed state-owned company in Malaysia. Future studies can adopt multiple-case study method to show the commonality and differences of the main actors, collaborators and institutions involved in the production of corruption. Secondly, our case study analysis relies on secondary data and future research may use interviews with members of political parties, lawyers, accountants, and this will provide better voices on the corruption problem. Thirdly, we did not discuss the preventive strategies suitable for the country and hence, future studies may consider this. Fourthly, as a multiracial and multi-religious nation, the underlying philosophical and ethical doctrines for conducting economic activities other than neoliberalism may be considered. 


\section{References}

Amundsen, I. (1999). Political corruption: An introduction to the issues, Working Paper 99:7, Bergen: Chr. Michelsen Institute.

Andvig, J,C., Fjeldstad, O., Amundsen, I., Sissener, T. \& Søreide, T. (2000). Research on Corruption: A policy oriented Survey, Report commissioned by Norad, Chr. Michelsen Institute (CMI) \& Norwegian Institute of International Affairs (NUPI), (available at: http://www.icgg.org/downloads/contribution07_andvig.pdf

Australasian Business Intelligence (23 May 2002), (available at: http://w3.nexis.com/sources/scripts/info.pl?290360).

Bakre, O. M. (2008). Financial reporting as technology that supports and sustains imperial expansion and control in the colonial and post colonial globalisation: The case of the Jamaican economy, Critical Perspectives on Accounting, Special Issue on Accounting for Global Warming: 431-486.

Bayart, J.F., Ellis, S. \& Hibou, B. (1999). The criminalization of the state in Africa, Oxford: Curry.

Boltanski, L. \& Chiapello, E. (2005). The new spirit of capitalism, London: Verso.

Borneopost (2012), http://www.theborneopost.com/2012/06/28/malaysia-a-goodexample-of-successful-islamic-country/\#ixzz3cDSPpBHv

Brooks, G., Walsh, D., Lewis, C. and Kim, H. (2013). Preventing Corruption: Investigation, Enforcement and Governance, London: Palgrave Macmillan.

Bush, G. (2006). Public Papers of the Presidents of the United States, Washington DC.: U.S.G.P.O. 2001-2009.

Chabal, P \& Daloz, J.P. (1999). Africa works: Disorder as political instrument, Oxford: International African Institute London.

Chang, H.J. (1998). Reform for the Long-Term in South Korea, International Herald Tribune. 13 February 1998.

Erickson, J. and Shameen, A, (1998). Mounting Pressure, Asiaweek, Mar. 2, 7.

Everett, J, Neu, D. \& Rahaman, A.S. (2006). The Global Fight against Corruption: A Foucaultian, Virtues-Ethics Framing, Journal of Business Ethics, 65, 1-12.

Everett, J, Neu, D. \& Rahaman, A.S. (2007). Accounting and the global fight against corruption, Accounting, Organizations and Society, 32 (2007) 513-542.

Girling, J. (1997). Corruption, Capitalism and Democracy. Routledge: Taylor and Francis Group.

Global Financial Integrity. (2014). Available at https://www.transparency.org/cpi2014/results (accessed 6 March 2015).

Gomez, E.T. \& Jomo, K.S. (1999). Malaysia’s Political Economy - Politics, Patronage and Profits, Cambridge University Press.

Gomez, E.T. The 2004 Malaysian General Elections: Economic Development, Electoral Trends, and the Decline of the Opposition. in Saw, S.H. and Kesavapany, K. (eds.). (2006). Malaysia: Recent Trends and Challenges. Singapore: Institute of Southeast Asian Studies. pp. 73-99. 
Grenfell, N. (1979). Switch On: Switch Off-Mass Media Audiences In Malaysia. Oxford University Press.

Haber, S. (2002). Crony Capitalism and Economic Growth in Latin America: Theory and Evidence. Stanford CA: Hoover Institution Press.

Harvey, D. (2005). A brief history of Neoliberalism, Oxford: Oxford University Press.

Hayek, F.A. (1944). The road to Serfdom, London: Routledge.

Heimann, F. and Boswell, N.Z. (1998). The OECD Convention: Milestone on the Road to Reform. In Transparency International (ed.), New Perspectives on Combating Corruption (Transparency International, Washington), pp. 65-74.

Hooker, V. and Othman, N. (2003). Malaysia: Islam, Society and Politics (ed.), Singapore: Institute of Southeast Asian Studies.

Hope, K.R. \& Chikulo, B.C. (2000). Decentralization, the new public management, and the changing role of the public sector in Africa, Public Management: An International Journal of Research and Theory, 2(1), 25-42.

Ibrahim, A. (2013). Shameless Malaysian Government Fraud Goes Global, TheWorldPost 02/28/2013, http://www.huffingtonpost.com/azeemibrahim/shameless-malaysian-gover_b_2773995.html

Johnston, M. (2005). Syndromes of Corruption: Wealth, Power, and Democracy, Cambridge University Press.

Jomo, K.S. (2003). Mahathir's Economic Legacy, Kyoto Review of Southeast Asia. Issue 4 October. Regional Economic Integration.

Krugman, P. (1998). What happened to Asia? Mimeo, Cambridge, MA: Department of Economics, Massachusetts Institute of Technology.

Leigh, M. (2001). Malaysia: 1961 and 2001, paper presented at the annual conference of the Association for Asian Studies, Chicago, March 2001, p. 7. Cited in Slater, D. (2003). Iron Cage in an Iron Fist: Authoritarian Institutions and the Personalization of Power in Malaysia. Comparative Politics, 36(1) (October 2003), 81-101.

Leong, H.K. (1992). Aggrandizement of Prime Minister's Power: The Transformation of the Office of the Prime Minister in Malaysia, Internationales Asien Forum, 23, p. 243, 236.

Lopez, L. (2000). Malaysia's perwaja steel continues to bleed red ink, mired in problems, The Wall Street Journal, June 12, http://www.wsj.com/articles/SB960744692936177300.

MACC (Malaysian Anti-Corruption Agency). (2012). Available at http://www.sprm.gov.my/files/MACC\%20ANNUAL\%20REPORT\%202012.pdf (accessed 27 March 2015).

Mann, M. (1988), States, War, and Capitalism: Studies in Political Sociology, Oxford: Basil Blackwell.

Netto, A. (1999). Mega-projects are back to boost Malaysian egos, Asia Times online, September 03, 1999, http://atimes.com/se-asia/AI03Ae02.html

Netto, A. (2004). Rural Malaysia mired in poverty, World Press Review, 51(1). 
Phillips, K.P (2004). American Dynasty: Aristocracy, Fortune, and the Politics of Deceit in the House of Bush. New York: Viking.

Rahman, E. (2002). State-led modernization and the new middle class in Malaysia. Palgrave: Houndmills and New York.

Rose, N. and Miller, P. (1992). Political Power Beyond the State: Problematics of Government, British Journal of Sociology, 43(2), 173-205.

Rose-Ackerman, S. (1999). Corruption and Government: Causes, Consequences and Reform, Cambridge, UK: Cambridge University Press.

Rose-Ackerman, S. (1978). Corruption: a study in political economy, Academic Press, University of Michigan.

Saw, S.H. and Kesavapany, K. (2006). Malaysia: Recent trends and challenges, Institute of Southeast Asian Studies.

Sikka, P. (2008). Enterprise culture and accountancy firms: New masters of the universe, accounting. Auditing and Accountability Journal, 21(2), 268-295.

Sikka, P. (2015). The corrosive effects of neoliberalism on the UK financial crises and auditing practices: A dead-end for reforms, Accounting Forum, 39, 1-18.

Sikka, P. \& Lehman, G. (2015). The supply-side of corruption and limits to preventing corruption within government procurement and constructing ethical subjects, Critical Perspectives on Accounting, 28, p.62-70.

Sklair, L. (1995). Sociology of the Global System, Baltimore: Johns Hopkins University Press.

Slater, D. (2003). Iron Cage in an Iron Fist: Authoritarian Institutions and the Personalization of Power in Malaysia, Comparative Politics, 36(1), 81-101.

Tanzi, V. (1998). Corruption around the world: Causes, consequences, scope and cures, IMF working paper WP/98/63, access http://www.imf.org/external/pubs/ft/wp/wp9863.pdf

Tebble, A.J. (2010). F.A. Hayek, London: Bloomsbury.

The Malay Mail Newspaper, Kuala Lumpur, Malaysia - several editions.

The News Straits Times Newspaper, Kuala Lumpur, Malaysia - several editions.

The Qur'an, Available at http://quran.com/11 (accessed on 11 June 2015).

The Staronline, Online. Several editions. Available at http://www.thestar.com.my.

Transparency International website, 2011 (accessed from https://www.transparency.org/cpi2014/results on 6 March 2015).

Wade, R. (1998). From 'Miracle’ to 'Cronyism': Explaining the Great Asian Slump. Cambridge Journal of Economics, 22(6).

Worldpress.org (accessed 20 March 2015).

WTF (2011). The Perwaja Steel Scandal, https://wtfreport.wordpress.com/2011/12/15/the-perwaja-steel-scandal/ 
Table 1 A summary of Perwaja finances in 1995

\section{INDEBTED}

\section{Major Malaysian lenders to Perwaja}

Bumiputra Merchant Bankers (syndicated loan)

\begin{tabular}{ccc} 
RM million & & Yr of Maturity \\
\cline { 1 - 1 } 135 & & 2003 \\
430 & & 2004 \\
270 & & 2007 \\
600 & & 2000 \\
600 & & 2002 \\
710 & & 2001
\end{tabular}

Arab-Malaysian Merchant Bank Bhd.

Arab-Malaysian Merchant Bank Bhd.

Arab-Malaysian Merchant Bank Bhd.

Arab-Malaysian Merchant Bank Bhd.

Employees Provident Fund

710

2001

\section{BILLS TO PAY}

Perwaja by the numbers:

Direct loans owed to the government

Outstanding loans guaranteed by government

(Local and foreign)

\begin{tabular}{ccc}
$\begin{array}{c}\text { RM million } \\
\text { End of 1998 }\end{array}$ & & $\begin{array}{c}\text { RM million } \\
\text { End of 1997 }\end{array}$ \\
\cline { 1 - 2 } RM 4,015m & & RM 3,174m \\
RM 5,122m & & RM 5,682m
\end{tabular}

\section{Major Foreign Lenders to Perwaja}

IBJ Leasing Services (Panama) Inc. Standard Chartered Bank (Labuan)

\begin{tabular}{|c|c|}
\hline RM million & Yr of Maturity \\
\hline 199.3 & 2003 \\
\hline 1,520 & 2002 \\
\hline 685.5 & 2003 \\
\hline
\end{tabular}

Japanese Banking Consortium

Source: Lopez (2000) based on Malaysian government sources. 
Table 2 Chronology of the emergence \& demise of Perwaja Steel

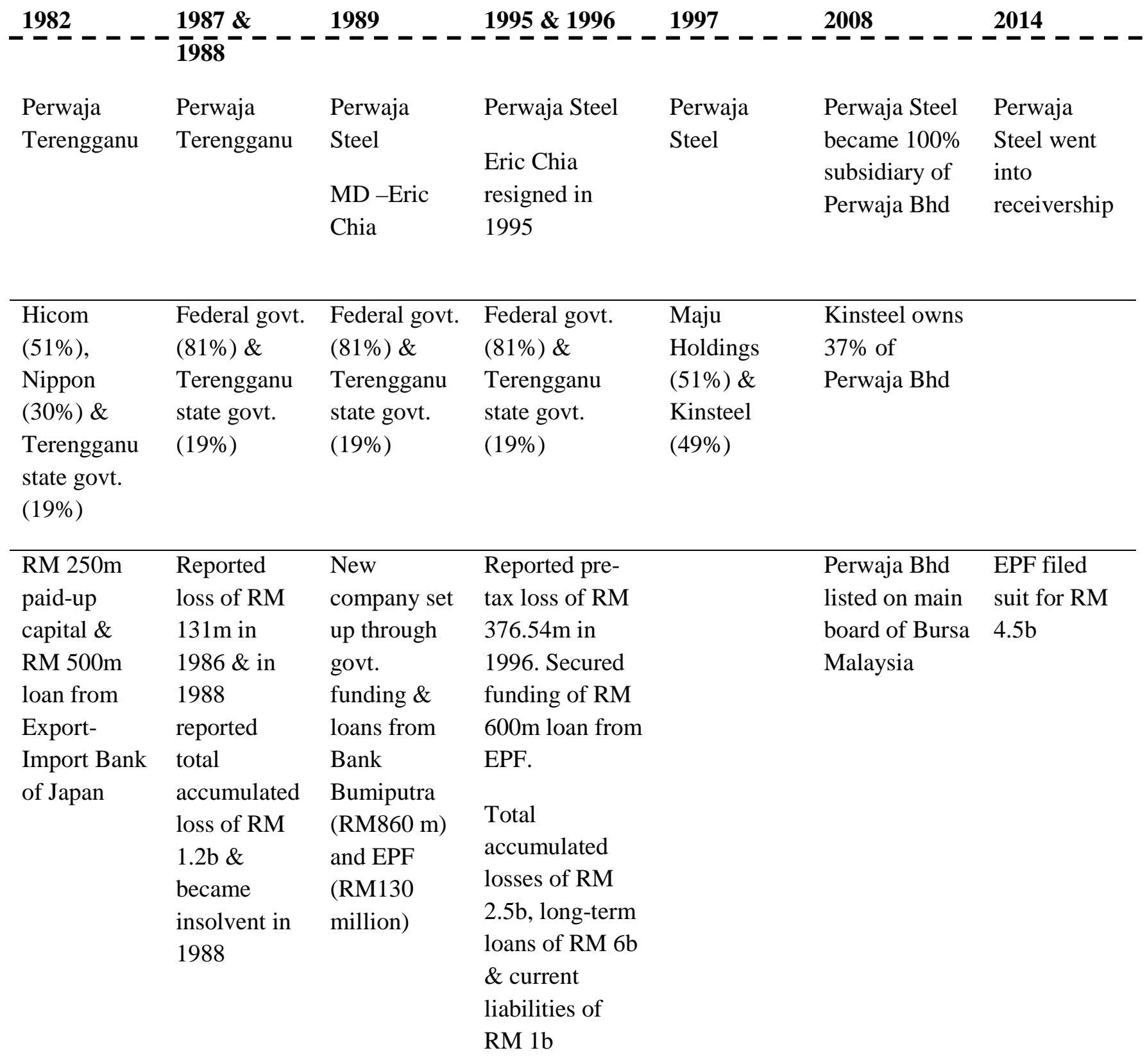


Figure 1 Deployment of power and production of corruption

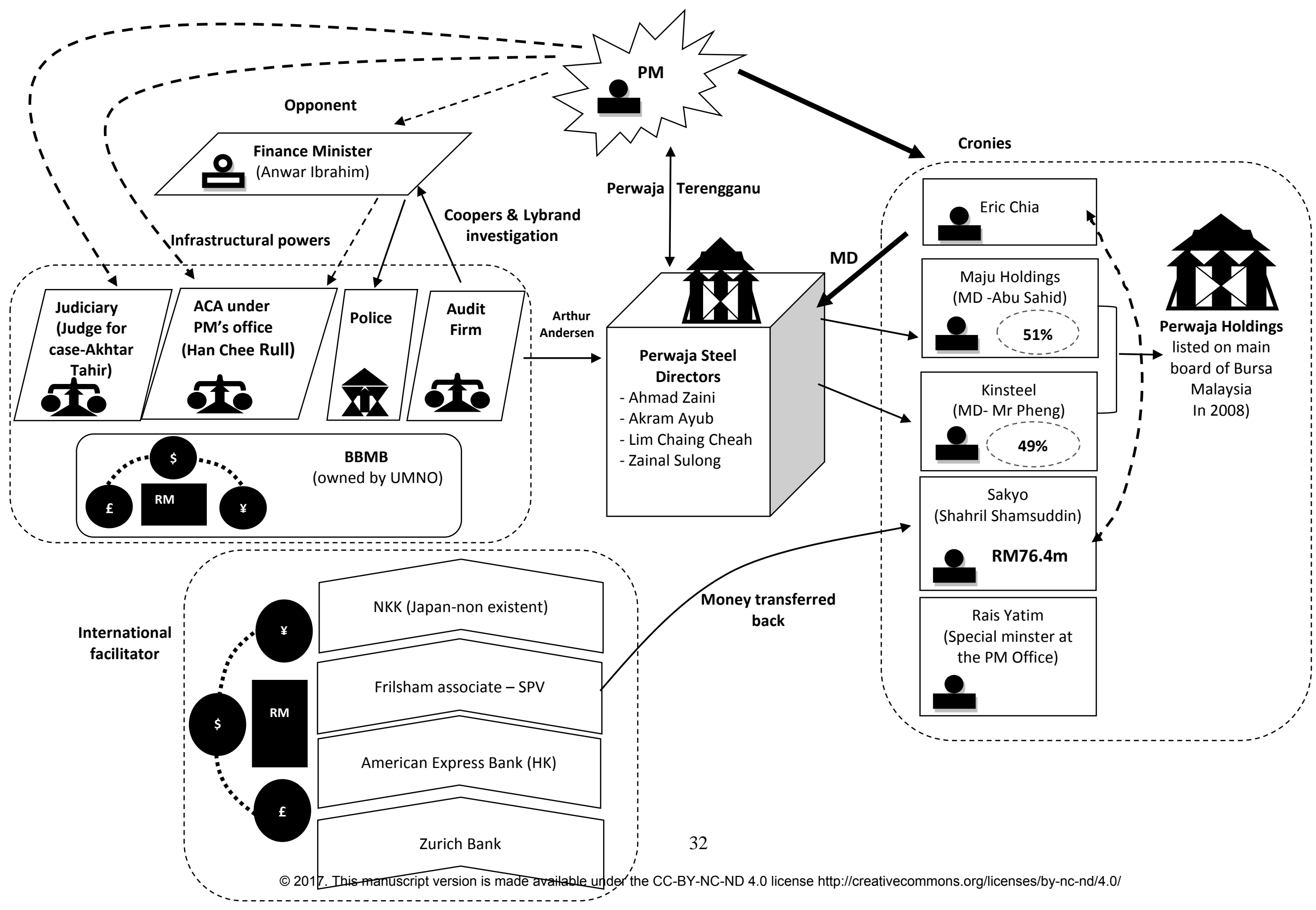


Table 3 Chronology of events of the Perwaja debacle

\begin{tabular}{|c|c|c|}
\hline Year & Events & $\begin{array}{l}\text { Neoliberalism \& Personalisation of power } \\
\text { by an autocrat }\end{array}$ \\
\hline 1982 & $\begin{array}{l}\text { Perwaja Terengganu was established as a joint } \\
\text { venture between the government and Nippon } \\
\text { Steel Corp of Japan in the east coast of } \\
\text { Malaysia although steel was consumed in huge } \\
\text { volumes in the west coast, which clearly is a } \\
\text { recipe for disaster. }\end{array}$ & $\begin{array}{l}\text { Mahathir justified his decision by claiming } \\
\text { that he was taking industrialisation to the } \\
\text { east coast of Malaysia to help develop the } \\
\text { state. }\end{array}$ \\
\hline 1986 & $\begin{array}{l}\text { Perwaja Terengganu accumulated losses of } \\
\text { RM } 131 \text { million. }\end{array}$ & $\begin{array}{l}\text { Mahathir blamed it on appreciation of the } \\
\text { yen and not on poor management skills of } \\
\text { his inexperienced cronies in the steel sector. }\end{array}$ \\
\hline 1987 & $\begin{array}{l}\text { Eric Chia mandated to investigate why the } \\
\text { project failed. }\end{array}$ & $\begin{array}{l}\text { Mahathir used Eric as his Mr Fixit to help } \\
\text { rescue his failing pet project. }\end{array}$ \\
\hline 1988 & Perwaja Terengganu went into solvency. & $\begin{array}{l}\text { Mahathir did not want to admit failure of his } \\
\text { project, hence rejected proposals to turn } \\
\text { around the company to profitable venture. }\end{array}$ \\
\hline 1988 & $\begin{array}{l}\text { Perwaja Steel was established and Eric was } \\
\text { appointed as managing director. }\end{array}$ & $\begin{array}{l}\text { Mahathir used one of the state agencies, } \\
\text { EPF to provide syndicated loan to help Eric } \\
\text { managed the new company. Representatives } \\
\text { from MOF sat on the board of the company. }\end{array}$ \\
\hline 1991 & Perwaja Steel recorded its first profit. & $\begin{array}{l}\text { Mahathir used the event to justify that his } \\
\text { action in appointing Eric to manage his new } \\
\text { project was correct to ward off criticisms on } \\
\text { his mega projects. }\end{array}$ \\
\hline 1995 & Eric Chia resigned from Perwaja Steel. & Mahathir ordered Eric to resign. \\
\hline 1996 & $\begin{array}{l}\text { Perwaja Steel reported a pre-tax loss of RM } \\
376.54 \text { million. }\end{array}$ & $\begin{array}{l}\text { Mahathir used EPF for the second time to } \\
\text { provide syndicated loan. }\end{array}$ \\
\hline 1996 & $\begin{array}{l}\text { Anwar Ibrahim disclosed in parliament } \\
\text { Perwaja’s actual loss to be RM2.9 billion } \\
\text { based on the report by Coopers \& Lybrand } \\
\text { who was tasked to investigate Perwaja } \\
\text { Terengganu's insolvency status. }\end{array}$ & $\begin{array}{l}\text { Anwar instructed ACA to begin } \\
\text { investigation on the company’s audited } \\
\text { report by Arthur Andersen for possible } \\
\text { malpractices and fraud that have contributed } \\
\text { to the loss. }\end{array}$ \\
\hline 1997 & $\begin{array}{l}\text { Maju Holdings Sdn Bhd bought } 51 \% \text { stake in } \\
\text { Perwaja Steel. }\end{array}$ & $\begin{array}{l}\text { Mahathir helped another of his Malay } \\
\text { crony, Abu Sahid to acquire the business } \\
\text { and only in } 2003 \text { the deal was inked and for } \\
\text { the company to assume control. }\end{array}$ \\
\hline 1998 & $\begin{array}{l}\text { Anwar Ibrahim was expelled from the } \\
\text { government as he was against injecting public } \\
\text { funds on failing projects and those that do not } \\
\text { benefit society. }\end{array}$ & $\begin{array}{l}\text { Mahathir used the judiciary institution to } \\
\text { imprison Anwar for sodomy allegation and } \\
\text { other corruption charges. }\end{array}$ \\
\hline 2004 & $\begin{array}{l}\text { Eric was arrested and charged of criminal } \\
\text { breach of trust involving RM } 76.4 \text { million. }\end{array}$ & $\begin{array}{l}\text { Abdullah Badawi who superseded Mahathir } \\
\text { used Eric's detention as a political ploy } \\
\text { ahead of the 2004's general election rather } \\
\text { than actually bringing the culprit to justice. }\end{array}$ \\
\hline 2007 & Eric was acquitted by the judge. & $\begin{array}{l}\text { The prosecution team failed to bring the key } \\
\text { witnesses and produced conflicting } \\
\text { documents causing the case to be dropped. }\end{array}$ \\
\hline
\end{tabular}

